\title{
Customer Experience and Behavioral Intentions: The Mediation Role of Customer Perceived Value
}

\author{
Fortune Edem Amenuvor ${ }^{1}$, Kwasi Owusu-Antwi ${ }^{2}$, Richard Basilisco ${ }^{3}$ Ph.D, Bae, Seong-Chan ${ }^{4}$ Ph.D \\ ${ }^{1} \mathrm{PhD}$ Candidate \\ Department of Business Administration Keimyung University South Korea \\ ${ }^{2}$ Lecturer \\ Department of Marketingn Methodist University College Ghana \\ ${ }^{3}$ Department of Global Entrepreneurship \\ Hanil University and Presbyterian Theological Seminary South Korea \\ ${ }^{4}$ Department of Social Welfare Hanil University and Presbyterian Theological Seminary South Korea
}

\begin{abstract}
The overarching aim of this research is to empirically test the effect of customer experience on customer perceived value and behavioral intentions while assessing the mediating role of customer perceived value. To achieve this aim, we collect data from 338 customers of restaurants in South Korea. The hypotheses intended to achieve this aim are tested using the structural equations modeling technique. The outcome of the research reveals that customer experience positively and significantly affects behavioral intentions. Additionally, customer experience has a significant positive effect on both hedonic and utilitarian value respectively. Hedonic value positively and significantly predicts behavioral intents while utilitarian value is negative but significantly related to behavioral intentions. The study further finds support for a mediating effect of hedonic value on the relationship between customer experience and behavioral intentions. The current study provides managerial and theoretical insights into understanding customer experience management, customer perceived value, and customer behavioral intentions.
\end{abstract}

Keywords: Customer Experience, Hedonic Value, Utilitarian Value, Behavioral Intentions

\section{Introduction}

The emergence of an experience economy has brought in its trail, the desire by many a scholar to expend more effort in exploring the knowledge of experiential marketing. Being one of the key undercurrents of experiential marketing, customer experience has been adopted as a benchmark to predict consumers' behavioral dispositions. Customer experience appears to create a point of convergence among professionals, experts and service scientists in discussing issues around customer service. The extant literature highlights that customer experience may be the god card in competition, especially, in this era of the experience economy (Meyer \& Schwager, 2007; Shaw \& Ivens, 2002). Customer experience has been conceptualized as the customer's cognitive, emotional, affective, social and physical response to providers of products and services (Verhoef, 2009).

One key area in which customer experience has gained relevance both in theory and practice is in the service sector, especially, the hospitality sector. Hospitality like any other service discipline appears to be replete with special complexities, underpinned by factors such as intangibility, subjectivity, perishability, social environmental considerations among others. Most services are gravitating towards commoditization, and hence, companies in the services industry are resorting to competing on experiences. Consequently, the idea of customer experience seems to have resonated with academics and practitioners alike impelling many to 
recently devote much practical and scholarly attention to the field (Dou, Zhu, Zhang, \& Wang, 2019; Kranzbühler, Kleijnen, Morgan, \& Teerling, 2018). Nonetheless, evidence within the extant literature suggests that research on customer experience appears to be young, compared to other services-related issues like loyalty and service quality. Regardless of the type of service a customer is patronizing, the customer goes through an experience-an encounter that provides them with an opportunity for emotional engagement (Berry \& Carbone, 2007; Carbone \& Haeckel, 1994; Johnston \& Kong, 2011). Customer experience, thus, becomes more relevant as far as customers' future behavioral dispositions and intentions are concerned.

Despite the burgeoning nature of the subject of customer experience, persistent calls for more scholarly works are consistently being made, given the fact that several gaps exist in the literature. Notable among the several observations and deficiencies in the extant literature is the inadequate studies examining customer experience from service-related sectors such as the restaurant setting. Secondly, prior research has also been inattentive to the impact of customer experience on customers' perceived (hedonic and utilitarian) value from a restaurant perspective. In effect, most customer experience studies scarcely factor in how it influences perceived value. Thirdly, there seems to be a blurring in the literature on how customers' perceived value mediates the nexus between customer experience and behavioral intentions (such as WOM intention and repurchase intention). Theoretically, evidence within the extant literature shows a paucity of research on customer experience that has used the expectancy disconfirmation theory (EDT) as the theoretical lens. Contextually, research on customer experience from a South Korean context remains very scanty as the majority of the existing studies have been spawned from the western and European contexts. Without clearly addressing these gaps, the customer experience (and by extension, relationship marketing) literature will continue to remain slightly deficient.

The foregoing gaps present key limitations in the literature given that firstly, the peculiarities of restaurant settings offer significant contributions to studying services issues in marketing and particularly tourism marketing/ management (Gummesson, 2014). Secondly, lack of recognition of the influence of customer experience on customer's perceived value and the mediating role it plays in the relationship between the former and behavioral intentions may cause marketing practitioners and scholars to be deluded with porous generalizations, especially in theory development (Bishmoi \& Kumar, 2016). Thirdly, theoretical models utilized in western contexts generally portray inconsistencies in other contexts (Dawar \& Chattopadhya, 2002; Sheth, 2011), engendering the calls for validations, in other contexts with unique characteristics, for the development of new theories, methodologies, and models (Burges \& Steenkamp, 2013).

Consequently, this study sets out to progress knowledge along the lines of the gaps elaborated, by empirically investigating how customer experience influences, behavioral intentions in restaurant services while empirically assessing the mediating role played by perceived value underpropped by the expectancy disconfirmation theory (EDT). To this end, customers of selected restaurants in South Korea are studied to test the theoretical constructs, and to augment the hospitality/tourism management literature with fresh empirical insights. The subsequent sections of the paper follow this order; theoretical background, literature review, hypothesis development, empirical data collection and analysis, discussion and conclusion, implications, limitations and future research.

\subsection{Theoretical Framework}

We adopt the expectancy disconfirmation theory (EDT) as the theoretical lens for this study.

\subsection{Expectancy Disconfirmation Theory}

The expectancy disconfirmation theory provides illumination to how customers perceive and become satisfied with a product or service offering. The theory is undergirded by the cognitive dissonance theory, promulgated by Festinger (1957) to elucidate how dissonance between customers' cognition and reality 
influence their consequent cognition and behavior (Bhattacherjee \& Premkumar, 2004). The expectancy disconfirmation theory measures customer experience and satisfaction from the disparity between their expectation and the actual experience of services and products (Patterson et al., 1996; Oliver, 1980). Due to its relevance, this theory has been adopted in offering explanations to a number of studies in various fields, such as psychology (Gotlieb et al., 1994); tourism (Fallon \& Schofield, 2003), marketing (Santos \& Boote, 2003; Diehl \& Poynor, 2010), information technology (Bhattacherjee \& Premkumar, 2004; Hsu et al., 2006), the airline industry (Chen, 2008) as well as repurchase behavior, behavioral intentions and retention (Patterson et al. 1996; Hsu et al., 2006) to provide better understanding for customers' expectation vis-à-vis satisfaction and consequent behavioral dispositions. The expectancy disconfirmation theory thrives on the premise that customers form expectation prior to purchasing a product or services. These expectations are used as thresholds and benchmarks for evaluating the actual performance and forming perceptions. The experience therefore becomes the point where the customer's expectation is met with actual delivery from which they form perceptions of value and behavioral intentions. This theory is relevant to this study and provides categories for analysis.

\subsection{Literature Review}

\subsubsection{Customer Experience}

The extant literature has operationalized customer experience as an incident, feeling, etc., which a person has undergone. It has also been argued that experiences yield sensory, emotional, cognitive, relational and behavioral values that substitute functional values (Schmitt, 1999). Customer experience emanates from a set of interactions that occur between customers, a company, a product or part of an organization which stimulates a reaction (Shaw \& Ivens, 2005; LaSalle \& Britton, 2003). This type of experience is personal and requires the customer's participation at different levels (emotional, rational, physical, sensory and spiritual) (Schmitt, 1999; LaSalle \& Britton, 2003). In effect, the evaluation of an experience is contingent on the customer's level of expectation and the stimuli emanating from the interaction with the company and its offering in consonance with the varied moments of touch points (Shaw \& Ivens, 2005).

Although the delineation of customer experience is not determinedly entrenched in literature, several operationalizations on what it represents have been offered by scholars. For instance, customer experience has been operationalized as a customer's personal interpretation of a service process as well as their interaction and involvement with it during the journey or process through a series of touchpoints and what these respective touchpoints make them feel (Ding et al., 2010; Johnston \& Clark, 2008; Meyer, 2007). Similarly, Vargo and Lusch (2004) note that experience and value are purely perceived from the perspective of an individual customer and hence, inherently personal, happening only in the customer's mind. Accordingly, Pine and Gilmore (1998) surmise that no two people could have the same type and degree of experience. A customer's experience of service results in feelings and emotions (which are powerful and subjective states of mind associated with physiological states (Purves et al., 2001). Some feelings that come along with customer experience may include, but not limited to, love, fear, surprise, anger, sadness, and shame. It may also include feelings that may range from, for instance, discomfort to depression, warm to intimate or ease to ecstatic (Johnston \& Kong, 2011; Goleman, 1996).

Growing evidence within the extant literature point to the fact that customer experience may become the new means of competition (Rajaobelina, 2018; Meyer, Schwager, 2007; Prahalad \& Ramaswamy, 2004; Voss et al, 2003; Shaw \& Ivens, 2002). Offering a good experience is crucial since it enhances customer satisfaction, increases customer loyalty, instills confidence, augments the brand, creates and as well sustains emotional bonds with customers (Flanagan et al., 2005; Pullman \& Gross, 2004; Mascarenhas et al., 2006). Customer experience emanates from a set of relationships between the customer and an object or service, company, or part of the company that triggers a response. This form of experience has been argued to be 
stringently personal and signals the consumer interaction at different levels (sensorial, physical, spiritual, emotional, and rational) (Gentile, Spiller \& Noci, 2007). Three key dimensions of customer experience have been provided in the extant literature. These are emotional experience, sensory experience, and social experience. (Schmitt, 1999). The subsequent section throws more light on these dimensions.

\subsubsection{Emotional Experience}

According to Schmitt (1999), emotional experience refers to the moods and emotions engineered during a shopping experience. Emotional experience generates effective experiences that span little positive moods and translates into a strong emotion of joy and gratification attached to a product/service (Yang \& He, 2011; Nasermoadeli et al., 2013). Emotional experience also depicts how a firm can create emotions (LeDoux, 1996). To this end, scholars have argued that customers who experience negative emotional responses are predisposed to having high brand switching behavior (Roos, 1999). Similarly, emotionally bonded consumers are inclined towards investing more in their relationship with a firm, compared to consumers who are not bonded emotionally or who lack affective commitment (Mattila, 2001). Consumers' emotional proximity with a firm is highly associated with their purchase disposition (Arnould \& Cost, 1993). It has been argued that customer experience and long-term behavioral intentions are influenced by the emotions created throughout the various phases of consumption (Barsky \& Nash, 2002).

\subsubsection{Sensory Experience}

Sensory experience has been conceptualized as the aesthetic and sensory perceptions about a firm's environment, atmosphere, service and/or products (Schmitt, 1999). The literature underscores that each of the five human senses (touch, taste, sight, sound, and smell) contribute to the development of an experience and all the senses work together to form the basis of sensory experience (Hulten, Broweus \& Dijk, 2009). Consumers' sensory experience creates what has been referred to as the "experience logic" which maintains that people's sensory experience in the brain and the experience evaluation that can guide subsequent behavioral, cognitive, emotional, relational and symbolic values relative to the services offered. Accordingly, the experience logic merges emotional and rational components in the mind to aid in the sensory experience of the product/service. Sensory experience has been argued to be a service in itself to customers and as such firms can utilize sensory marketing techniques with the motive of producing an enhanced sensory experience (Nasermoadeli et al., 2013; Lindsorm, 2005).

\subsubsection{Social Experience}

Akin to the foregoing, Schmitt (1999) operationalizes social experience as the relationship with society and others. Any social form of experience can produce effect toward individuals in the socializing process through peer groups, family, schooling, as well as mass media. These social impacts have the tendency of influencing thoughts, feelings, and actions. For instance, associating with peer groups enables individuals to acquire needed experiences in creating social links on their own and creating a sense of themselves (Nasermoadeli et al., 2013; Macionis \&Plummer, 1997). Olsen (1993) contends that aside peer groups, mass media (e.g. radio, television, etc.) also generate impacts on individuals through the socialization process which Griffiths contends may influence individuals' behavior.

\subsubsection{Customer Perceived Value}

A key concept for understanding customers in the service industry is perceived value (Jensen, 1996; Ostrom \& Iacobucci, 1995). Prior research highlights customers' perceived value as a multi-dimensional construct (Gronroos, 1997; Sweeney \& Soutar, 2001; Ha \& Jang, 2009) and has been approached through several lenses. For instance, Gronroos conceptualizes perceived value as a cognitive and emotional construct. Sheth et al. (1991) view perceived value from emotional, social, functional, conditional and epistemic value 
perspectives. Similarly, Sweeny and Soutar (2001) conceptualize perceived value from three dimensions: social dimension, functional dimension, and emotional dimension. Additionally, other scholars have operationalized perceived value from hedonic and utilitarian perspectives and have posited that these best describe customers' perceived value (Park, 2004; Voss et al., 2003; Jones et al., 2006; Ha \& Jang, 2009). The hedonic dimension of a product/service experience emanates from a service's symbolic meaning, uniqueness, imagery or emotional arousal that it elicits (Spangenberg et al., 1997). In lending support to the preceding conceptualization, Overby and Lee (2006) describe hedonic value as comprising customers' overall valuation of experiential benefits and sacrifices such as escapism and entertainment. On the other hand, the Utilitarian construct relates to task-specific, efficient and economical components of services (or products). Overby and Lee (2006) operationalize utilitarian value as an overall valuation of sacrifices and functional benefits. Utilitarian value, consequently, incorporates more cognitive facets of attitude such as judgments of time-saving and convenience as well as economic value for money (Teo, 2001; Ha \& Jang, 2009).

\subsection{Hypotheses Development}

\subsection{Customer Experience and Behavioral Intention}

Customers' benefits from utilizing and experiencing a service may include their perception of how they have gained or profited from the service provided and how they experienced it (how their expectations were met) (Johnston \& Kong, 2011). Drawing from Zomerdikj and Voss (2010), an outcome of a service from a customer's perceptive may be in the form of their conscious and unconscious assessment of the service provided. It may also involve the perceived value of the service received as well as their overall satisfaction and/or dissatisfaction (Carbone, 2004; Oliver, 1997; Bitner \& Hubbert, 1994). Consequently, these postexperience judgments will influence consumers' intentions with regards to repurchasing or not, recommendations to others or complaint intentions. We, therefore, operationalize behavioral intention as encompassing bother word-of-mouth recommendations and repurchasing. Accordingly, this research (based on the preceding discussion) argues that customers' experience will influence their behavioral intentions and hence we submit the following hypothesis:

H1: There is a positive and significant relationship between customer experience and behavioral intentions

\subsection{Customer Experience and Perceived Value (Hedonic and Utilitarian)}

The concept of perceived value (from a hedonic and utilitarian perspective) though very relevant in influencing consumers' behavior, has been given little research attention (Ha \& Jang, 2009; Park, 2004). Finkel-stein (1989) notes that a restaurant is a place where customers satiate hunger needs as well as excitement, pleasure, experience and a feeling of emotional well-being. We argue, therefore, that the nature of the experiences in restaurants requires that restaurant operators inculcate both utilitarian and hedonic aspects in their customer service operations. The practical and theoretical relevance of this argument is premised on the fact that restaurant customers are triggered by several motivations to eat out which include, but not limited to fun, social interaction, taste, efficiency and economic reasons (Park, 2004; Ha \& Jang, 2009). Accordingly, customers mostly perceive utilitarian value through a comparison of food and service quality with the amount of money spent on services and food. Additionally, customers perceive hedonic value by evaluating the excitement and enjoyment induced while eating at a restaurant. It, therefore, stands to reason that consumers' perceptions of value concerning restaurant experience may be developed based on their assessment of both economic or functional benefits as well as affective and emotional elements. Accordingly, consumers' value perceptions become critical benchmarks for future behavioral intentions. We, therefore, consider customer's perceived hedonic and utilitarian values as key outcomes of customer experience. On this basis, we advance the following hypotheses: 
$\mathrm{H} 2$ : There is a positive and significant relationship between customer experience and perceived hedonic value.

H3: There is a positive and significant relationship between customer experience and perceived utilitarian value.

\subsection{Customer Perceived Value and Behavioral Intentions}

Scholarly evidence suggests that customers' perceived value is a sine qua non to their purchase decision making, accentuating the position that behavioral intentions are key outcomes of perceived value (Zeithaml, 1988). Consumers tend to express positive behavioral dispositions when they perceive high degrees of value from a consumption experience (Sweeney \& Soutar, 2001). For this study, we focus on repurchase intention and word-of-mouth intention as key dimensions of behavioral intentions. We argue that utilitarian value has a positive influence on repurchase intention based on the fact that customers who perceive economic and efficient value from their previous experiences have a greater predisposition to repurchase from the same service provider. Similarly, we maintain that hedonic value has a positive influence on repurchase intention, based on the fact that customers who perceive value through affective and emotional experiences will be impelled to repurchase from the same provider (Donovan \& Rossiter, 1982; Swinyard, 1993; Ha \& Jang, 2009). Extant research further emphasizes that word of mouth is one of the most powerful tools of communication. Most customers perceive word-of-mouth information as more reliable, purely because it is based on the source's experience. To this end, Swan and Oliver (1989) reckon that word-of-mouth is a consequence of the customer's emotional responses to consumption experiences. We argue that the more consumers value the affective dimensions of restaurant experience, the more likely they are of spreading positive word-of-mouth about same. By implication, the hedonic value may have a positive impact on positive word-of-mouth. Further, word-of-mouth is linked to cognitive evaluations of consumers' consumption experience, triggering a possible relationship between utilitarian value and positive word-ofmouth. Consequently, and based on the foregoing discussion, we propose that:

H4: There is a positive and significant effect of hedonic value on behavioral intentions.

H5: There is a positive and significant effect of utilitarian value on behavioral intentions.

H6: Hedonic value will mediate the relationship between customer experience and behavioral intentions, H7: Utilitarian value will mediate the relationship between customer experience and behavioral intentions

Figure 1. Conceptual Framework

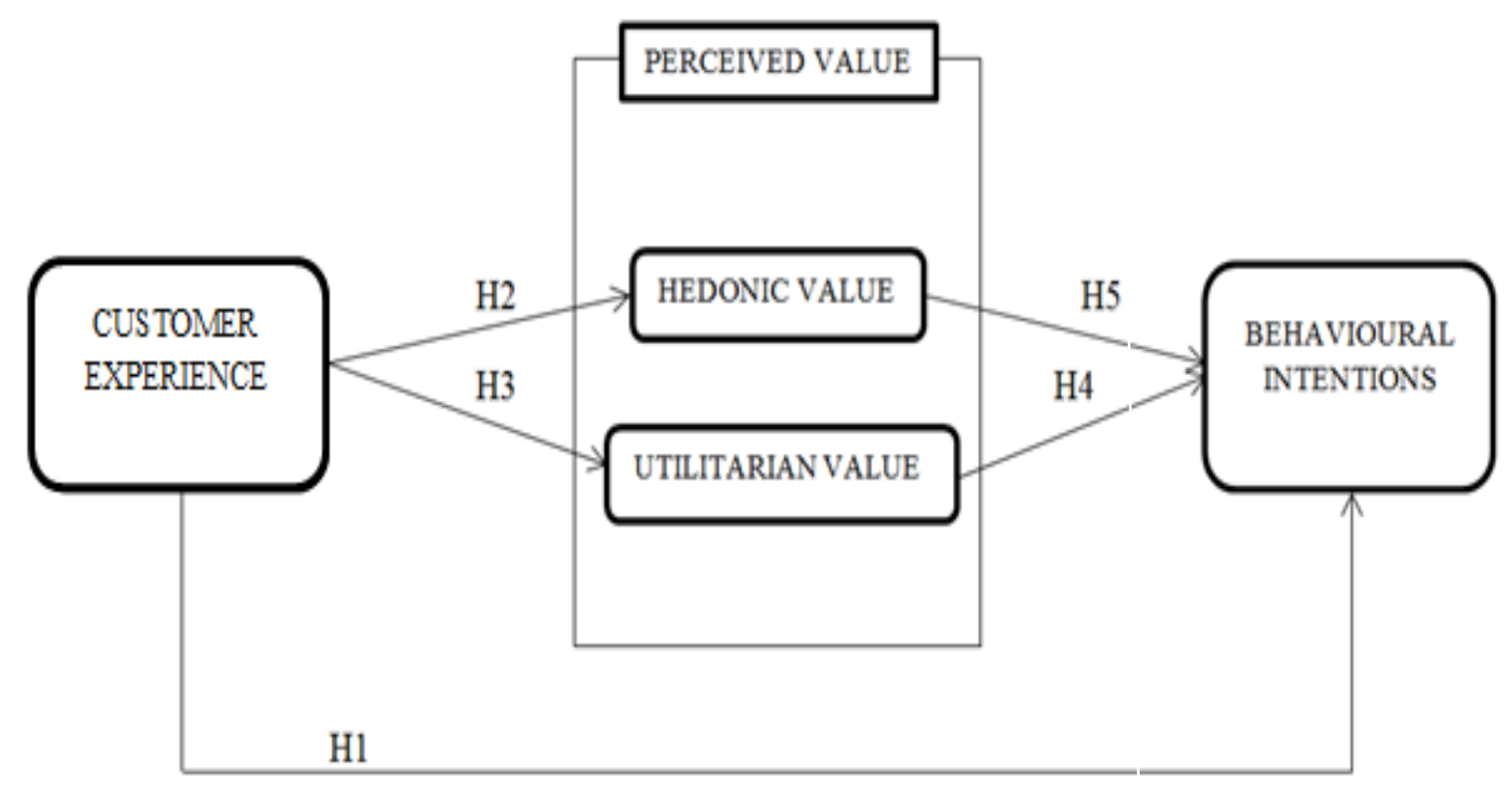

\subsection{Empirical Results}




\subsection{Measurement of Variables}

The study adopted a quantitative research approach using structured questionnaires. This was to make it possible for the calculations of actual statistical measures of theorized hypotheses on empirical data (Hair et al., 2010). Variables in the questionnaire encompassed measures on customer experience, perceived value, and behavioral intentions. The statements measuring these constructs were assessed on a five-point Likert scale anchored with " $1=$ strongly disagree" to " $5=$ strongly agree" and " $3=$ neutral". We operationalized all directional constructs (independent and dependent variables) with reflective measures. In operationalizing the measures, items for customer experience were adapted from prior research (Shaw \& Ivens, 2005; LaSalle \& Britton, 2003). Items for utilitarian value and hedonic value were both adapted from Park (2004) as well as Ha and Jang (2009), while items for behavioral intentions were adapted from previous research (Swan \& Oliver, 1989; Donovan \& Rossiter, 1982; Swinyard, 1993; Ha \& Jang, 2009).

The second part of the questionnaire dwelt on the demographic information of the respondents (age, gender, and period of a transaction with a restaurant). Using scale generation and purification processes and techniques proposed by scholars (King et al., 2014; DeVellis, 2003; Flynn \& Pearcy, 2001), all the scale items were purified, with the use of confirmatory factor analysis. Additionally, we employed the structural equation modeling (SEM) approach in evaluating the various hypotheses stated early on in this study. According to Bagozzi and Yi (2012) and Byrne (2013), the SEM is a preferred modeling approach due to its capacity to grant researchers the leverage to control measurement error, test multiple relationships and also provide information on the degree of fit of tested constructs.

\subsection{Samples and Data Collection}

We collected data from customers of restaurants in South Korea. We purposively selected the customers after their agreement to take part in the study. A total of 380 customers were sampled for this study. Before we administered the questionnaire, an adequate evaluation of the psychometric properties of the scale items was done by testing for face and content validity through the use of marketing consultants and University Professors (Bagozzi \& Yi, 1988). Of the 380 customers that were contacted, 352 responses were returned from which fourteen (14) had irregularities and had to be discarded. Eventually, we made use of 338 valid and fully filled questionnaires which showed enough adequacies for the intended analysis. The final usable data consequently represented a response rate of $88.9 \%$.

\subsection{Profile of Respondents}

The results from the distribution of the characteristics of the customers showed that the sampled respondents were adequately represented. As is depicted in Table 1, a profiling of the customers showed that $57.7 \%$ of them are males while $42.3 \%$ are females. The results revealed that majority $(56.2 \%)$ are between the ages 26-35years, followed by $28.1 \%$ between 18 -25years, whiles $12.1 \%$ are between the ages $36-45$ years. The data further revealed that $3.6 \%$ are at least 45 years old. In terms of education level, $13.0 \%$ had high school education as their highest level of education, a majority (48.5\%) indicated bachelor's degree, and $34.9 \%$ indicated master's degree while 3.6\% indicated that they have a doctorate. With respect to the period of transaction with the respective restaurants, majority (43.2\%) indicated they have been patronizing that restaurant for a period between 4-6years, 34.3\% indicated they have been eating form this restaurant for a period of 7-9years, $19.5 \%$ indicated at least 10 years, while $3.0 \%$ stated they have been eating from their respective restaurant for a period between 1-3years. 
Table 1- Profile of Respondents

\begin{tabular}{|c|c|c|c|c|c|c|c|}
\hline \multicolumn{2}{|c|}{ Classification } & $\mathrm{N}$ & $\%$ & \multicolumn{2}{|l|}{ Classification } & $\mathrm{N}$ & $\%$ \\
\hline \multirow[t]{2}{*}{ Gender } & Male & 195 & 57.7 & \multirow{6}{*}{$\begin{array}{l}\text { Period of } \\
\text { Transaction }\end{array}$} & \multirow[t]{2}{*}{ 1-3 Year } & \multirow[t]{2}{*}{10} & \multirow[t]{2}{*}{3.0} \\
\hline & Female & 143 & 42.3 & & & & \\
\hline \multirow[t]{4}{*}{ Age } & $\begin{array}{l}18-25 \\
\text { Year }\end{array}$ & 95 & 28.1 & & 4-6 year & 146 & 43.2 \\
\hline & $\begin{array}{l}26-35 \\
\text { Year }\end{array}$ & 190 & 28.1 & & 7-9 Year & 116 & 34.3 \\
\hline & $\begin{array}{l}36-45 \\
\text { year }\end{array}$ & 41 & 12.1 & & \multirow[t]{2}{*}{ Above $\overline{10 \text { year }}$} & \multirow[t]{2}{*}{66} & \multirow[t]{2}{*}{$19 . \overline{5}$} \\
\hline & $\begin{array}{l}\text { Above } \\
45 \text { Years }\end{array}$ & 12 & 3.6 & & & & \\
\hline \multirow{4}{*}{\multicolumn{5}{|c|}{ Education }} & Hiw School & 44 & 13.0 \\
\hline & & & & & Bachelors & 164 & 48.5 \\
\hline & & & & & Masters & 118 & 34.9 \\
\hline & & & & & Doctorate & 12 & 3.6 \\
\hline
\end{tabular}

\subsection{Reliability and Validity Analysis of Variables}

In the spirit of Fornell and Larcker (1981), the reliability of the measurement scales was evaluated by examining the loadings and the internal consistencies on their respective constructs. The results revealed standard estimates that ranged from 0.664 to 0.944 with internal consistency (Cronbach's Alpha) values that ranged from 0.839 to 0.938 . The authors employed confirmatory factor analysis (CFA) to test for the measurement model. Hair et al (2010) argue that most model-fit indices must attain the adequate standards to be qualified for model fitness. As Table 2 reveals, all the CFA indicators exceeded the recommended values, signaling adequate fit to the data gathered. The CFA fitted well, in addition to all the indices satisfying their specific threshold levels. Following from Anderson and Gerbing (1988), $x^{2} / \mathrm{df}=2.231$, $\mathrm{RMR}=.021$, GFI=.914, NFI=.983, IFI=.962, TLI=.955, CFI=.962, and RMSEA=.060. With factor loadings at a significant level of 1 percent, the convergent validity of the variables was reinforced (Bagozzi \& Yi, 1988). Also reported in Table 2 is the average variance extracted (AVE) that ranged from 0.726 to 0.892. Furthermore, by comparing shared AVE values between pairs of constructs with their squared phi correlations, discriminant validity was established. In all the cases, AVE values were greater than the shared squared phi correlations connected with each pair of constructs. This implies discriminant validity, which suggests that the constructs are distinct from one another as underscored by Fornell and Larcker (1981). The correlation coefficients also ranged from 0.227 to 0.631 . Table 3 shows the results of the descriptive statistics and inter-construct correlations.

Table 2- Measurement Model

\begin{tabular}{|c|c|c|c|c|c|c|c|}
\hline Item & Construct & Estimate & Std.Err. & t-value & (CR) & $\mathrm{p}$ & $\begin{array}{l}\text { Cronbach'sAlpha } \\
=\end{array}$ \\
\hline CE4 & \multirow{4}{*}{$\begin{array}{l}\text { Customer } \\
\text { Experience }\end{array}$} & 0.944 & & & \multirow[t]{4}{*}{0.939} & & \multirow[t]{4}{*}{0.938} \\
\hline CE3 & & 0.936 & 0.031 & 33.022 & & *** & \\
\hline CE2 & & 0.859 & 0.036 & 25.467 & & $* * *$ & \\
\hline CE5 & & 0.822 & 0.039 & 22.770 & & $* * *$ & \\
\hline UV2 & \multirow{5}{*}{$\begin{array}{l}\text { Utilitarian } \\
\text { value }\end{array}$} & 0.901 & & & \multirow[t]{5}{*}{0.883} & & \multirow[t]{5}{*}{0.88} \\
\hline UV3 & & 0.791 & 0.048 & 18.044 & & $* * *$ & \\
\hline UV5 & & 0.754 & 0.053 & 16.708 & & $* * *$ & \\
\hline UV4 & & 0.757 & 0.052 & 16.833 & & $* * *$ & \\
\hline UVl & & 0.664 & 0.050 & 13.841 & & $* * *$ & \\
\hline
\end{tabular}




\begin{tabular}{|c|c|c|c|c|c|c|c|}
\hline & \multirow{5}{*}{$\begin{array}{l}\text { Behavioral } \\
\text { intentions }\end{array}$} & & & & \multirow{5}{*}{0.907} & & \multirow{5}{*}{0.905} \\
\hline B12 & & 0.923 & & & & & \\
\hline Bll & & 0.892 & 0.037 & 24.985 & & $* * *$ & \\
\hline $\mathrm{BI} 3$ & & 0.787 & 0.045 & \begin{tabular}{|l|}
19.329 \\
\end{tabular} & & $* * *$ & \\
\hline BI4 & & 0.758 & 0.047 & 18.056 & & $* * *$ & \\
\hline HV3 & \multirow{4}{*}{$\begin{array}{l}\text { Hedonic } \\
\text { value }\end{array}$} & 0.732 & & & \multirow[t]{4}{*}{0.847} & & \multirow[t]{4}{*}{0.839} \\
\hline HV4 & & 0.784 & 0.067 & 13.440 & & $* * *$ & \\
\hline HV2 & & 0.755 & 0.074 & \begin{tabular}{|l|}
12.970 \\
\end{tabular} & & $* * *$ & \\
\hline HV5 & & 0.747 & 0.083 & 12.842 & & $* * *$ & \\
\hline
\end{tabular}

Table 3-Descriptives Statistics and Correlations

\begin{tabular}{|l|l|l|l|l|l|c|}
\hline & Mean & St.d. & 1 & 2 & 3 & 4 \\
\hline Customer Experience (1) & 3.9576 & 0.63126 & 0.892 & & & \\
\hline Utilitarian Value (2) & 3.1533 & 0.46457 & $0.354 * * *$ & 0.777 & & \\
\hline Behavioral Intentions (3) & 4.0902 & 0.77044 & $0.631 * * *$ & $0.227 * * *$ & 0.843 & \\
\hline Hedonic Value (4) & 3.6477 & 0.67916 & $0.508 * * *$ & $0.472 * * *$ & $0.593 * * *$ & 0.726 \\
\hline
\end{tabular}

Note: Significance of Correlations: ${ }^{\dagger} \mathrm{p}<0.100,{ }^{*} \mathrm{p}<0.050, * * \mathrm{p}<0.010,{ }^{* * *} \mathrm{p}<0.001$

\subsection{Model Fit and Hypothesis Test}

The parameter estimates shown in Table 4 represent the final results which provide a better authentication to the findings of the study in line with the proposed hypotheses. The model fit indices for the structural model showed confirmation of a good model fit (Model fit: $x^{2} / \mathrm{df}=1.927, \mathrm{RMR}=.021$, GFI $=.927, \mathrm{NFI}=.943$, $\mathrm{IFI}=.972$, TLI=.966, CFI=.971, RMSEA=.052). The first hypothesis (H1) states that there is a positive and significant effect of customer experience on behavioral intentions. The structural equations modeling results indicated that there was a positive and significant relationship between customer experience and behavioral intentions $(\beta=.465, \mathrm{t}=8.600, \mathrm{p}<0.05)$. The second hypothesis $(\mathrm{H} 2)$ states that customers' experience at a restaurant will have a positive and significant effect on their perceived hedonic value. The structural equations modeling results indicated that there was a positive and significant influence of customer experience on hedonic value $(\beta=.508, \mathrm{t}=8.459, \mathrm{p}<0.05)$. The third hypothesis states that customers' experience at a restaurant will have a positive and significant effect on their perceived utilitarian value. Consistently, the SEM results showed a positive and statistically significant effect of customer experience on utilitarian value $(\beta=.354, \mathrm{t}=6.297, \mathrm{p}<0.05)$. The fourth hypothesis (there is a positive and significant effect of hedonic value on behavioral intentions) was also positive and statistically significant $(\beta=.421, \mathrm{t}=$ 2.557, $\mathrm{p}<0.05$ ). The fifth hypothesis of the study (there is a positive and significant effect of utilitarian value on behavioral intentions) however was not supported $(\beta=-.136, \mathrm{t}=6.498, \mathrm{p}>0.05)$. Hypothesis 6 stated that hedonic value will mediate the relationship between customer experience and behavioral intentions. As table 5 shows, hedonic value (HV) partially mediates the relationship between customer experience and behavioral intentions as both the direct effect with the mediator $(\mathrm{CE} \rightarrow \mathrm{HV} \rightarrow \mathrm{BI}: \beta=.230, \mathrm{p}=$ $0.001)$ and the indirect effect $(\mathrm{CE} \rightarrow \mathrm{BI} ; \beta=.501, \mathrm{p}=0.000)$ were both significant. However, hypothesis 7 which stated that utilitarian value will mediate the relationship between customer experience and behavioral 
intentions was not supported $(\mathrm{CE} \rightarrow \mathrm{UV} \rightarrow \mathrm{BI}: \beta=-.048, \mathrm{p}=0.70)$. In effect, all the hypotheses (except for hypothesis seven (7) were supported.

\section{Table 4. Structural Model and Assessment Results}

\begin{tabular}{|c|c|c|c|c|c|}
\hline Structural Relationships & P Estimate & Std.Err. & t-value & $\mathrm{p}$ & Decision \\
\hline $\begin{array}{l}\text { (HI) Behavioral intentions f-Customer } \\
\text { experience }\end{array}$ & 0.465 & 0.058 & 8.600 & $* * *$ & Supported \\
\hline (H2) Hedonic value f-Customerexperience & 0.508 & 0.046 & 8.459 & $* * *$ & Supported \\
\hline (H3)Utilitarian value f- Customer experience & 0.354 & 0.070 & 6.297 & $* * *$ & Supported \\
\hline (H4) Behavioral intentions f-Hedonic value & 0.421 & 0.091 & 6.498 & $* * *$ & Supported \\
\hline (HS) Behavioral intentionf-Utilitarian value & -0.136 & 0.046 & -2.557 & 0.11 & $\begin{array}{l}\text { Not } \\
\text { supported }\end{array}$ \\
\hline
\end{tabular}

(Model fit: $\mathrm{x} 2 / \mathrm{df}=1.927$, ruvr:R.= .021, GFI=.927, NFI= .943, IFI=.972, TLI=.966, CFI=.971, RMSEA=.052)1

Table 5. Summary of Mediation Test

\begin{tabular}{|l|l|c|c|c|l|l|}
\hline \multicolumn{2}{|l|}{ Unstandardized regression path } & BEstimate & Lower & $\begin{array}{l}\text { Upper } \\
\text { results }\end{array}$ & $\begin{array}{l}\text { p- } \\
\text { value }\end{array}$ & Hypothesis \\
\hline $\begin{array}{l}\text { Direct effect } \\
\text { without } \\
\text { mediator }\end{array}$ & $\begin{array}{l}\text { Customer experience ---> } \\
\text { Behaviora 1 } \\
\text { intentions }\end{array}$ & 0.465 & - & - & $\begin{array}{l}\text { Supported } \\
\text { partial } \\
\text { mediation as }\end{array}$ \\
\hline $\begin{array}{l}\text { H6 (Indirect } \\
\text { effect }\end{array}$ & $\begin{array}{l}\text { Customer experience --- } \\
>\text { Hedonic value }\end{array}$ & 0.230 & 0.142 & 0.340 & 0.001 & $\begin{array}{l}\text { both direct } \\
\text { and }\end{array}$ \\
\hline with mediator!) & $--->$ Behavioral intentions & & & & $\begin{array}{l}\text { indirect paths } \\
\text { are } \\
\text { si1U1ificant }\end{array}$ \\
\hline $\begin{array}{l}\text { H7(indirect } \\
\text { effect } \\
\text { with mediator2) }\end{array}$ & $\begin{array}{l}\text { Customer experience ---> } \\
\text { Utilitarian value } \\
--->\text { Behavioral intentions }\end{array}$ & -0.048 & -0.101 & -0.005 & 0.070 & $\begin{array}{l}\text { Not } \\
\text { supported }\end{array}$ \\
\hline
\end{tabular}




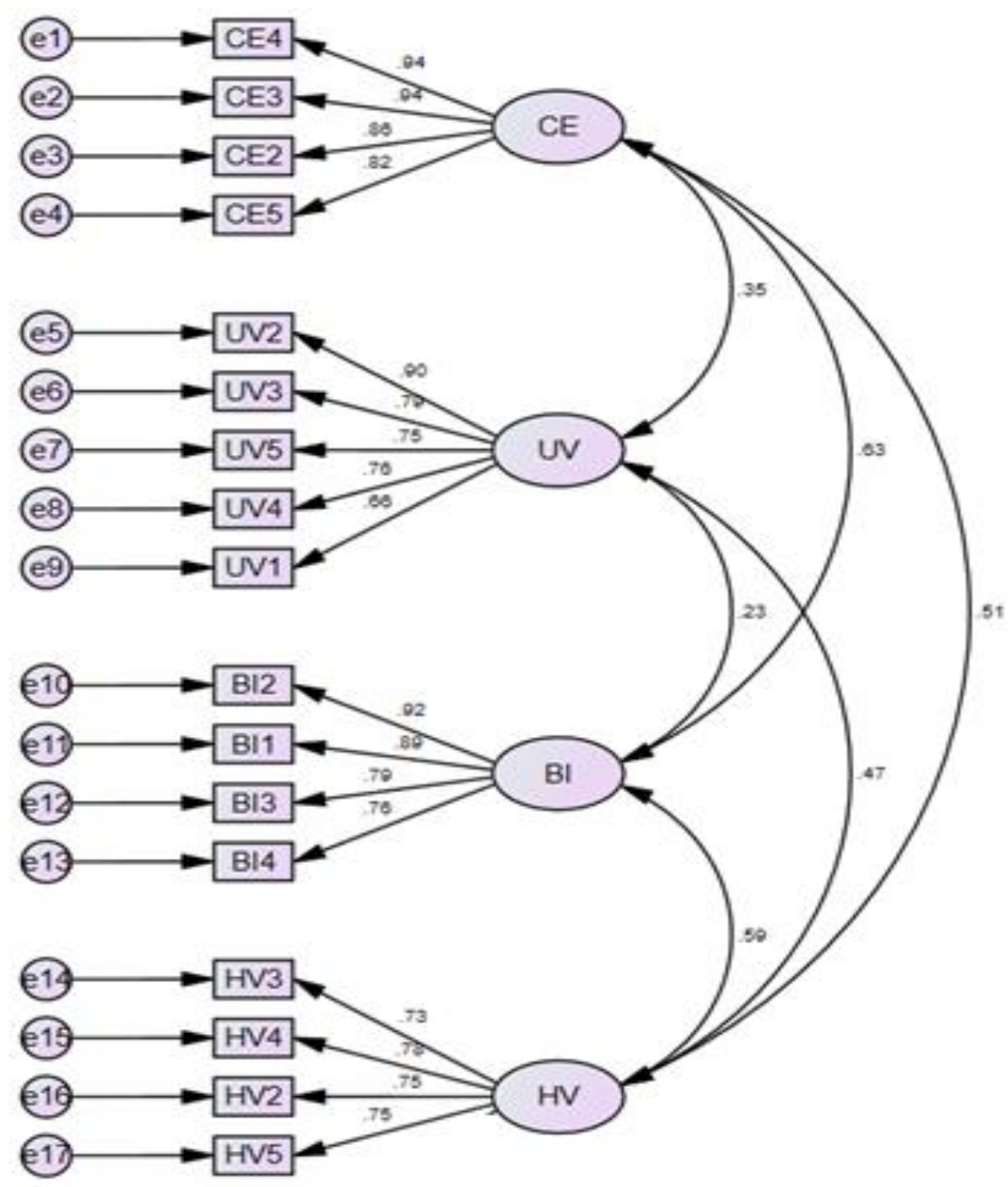

Figure 2. Final Measurement Model

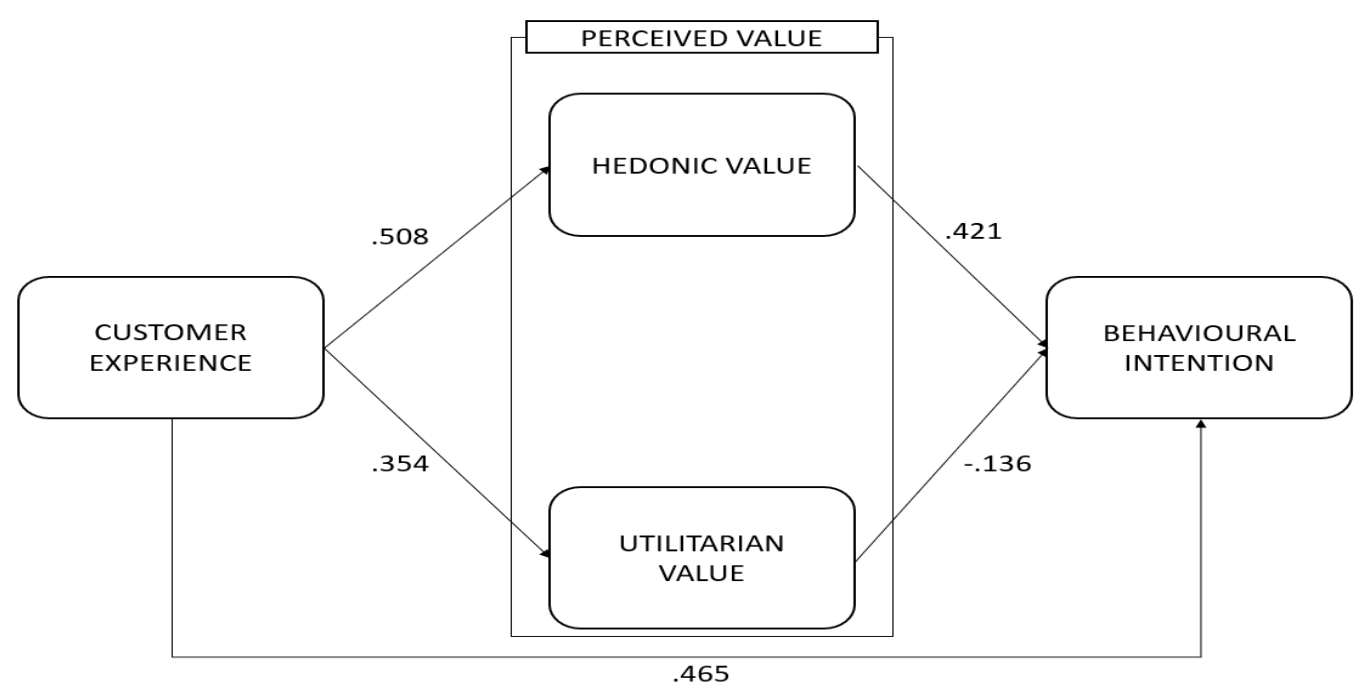

Figure 3. Structural model 


\subsection{Summary And Conclusions \\ 4.1 Summary of Findings}

This study throws light on how customer experience leads to value perceptions and how the latter influences behavioral intentions. It also seeks to examine the mediating role of perceived value in the same relationship. The study examined these relationships grounded on the expectancy disconfirmation theory. In general, the study found customer experience as germane to a customer's behavioral intentions. This outcome is consistent with previous research (Carbone, 2004; Oliver, 1997; Bitner \& Hubbert, 1994) which posit that customers' post-experience judgments (whether good or bad) will influence their intentions relative to repurchasing or not, recommendations to others or complaint intentions. Secondly, the results reveal a positive and significant effect between customer experience and (multilevel) perceived value. This outcome lends credence to prior research (Park, 2004; Ha \& Jang, 2009) which have demonstrated that customers perceive hedonic and utilitarian value by evaluating the excitement and enjoyment induced while dining at the restaurant as well as the overall assessment of sacrifices and functional benefits. Specifically, Teo (2001) and Overby and Lee (2006) surmise that customer experience triggers perceptions of value that serves as the impetus for future behavioral dispositions. Thus, in congruence with prior research, our study buttresses the position that customer experience is a major antecedent to the customer's perceived value. Our results further lend support for the positive and significant relationship between hedonic value and behavioral intentions. Precisely, the results revealed that hedonic value has a positive and significant effect on behavioral intentions. This finding is consistent with Zeithaml (1988) and Sweeney and Soutar (2001) who found that customers' perceived hedonic value is a sine qua non to their purchase decision making and behavioral intentions. However, the results could not find support for the positive and significant relationship between utilitarian value and behavioral intentions. This outcome, though unexpected, lends credence to the assertion that most customers use the hedonic value perceived in their interaction with services more (which is more emotional) than the utilitarian value which is mostly functional and economic (Park, 2004; Ha \& Jang, 2009). The point of departure of this research from extant literature however, is that while extent research has overlooked the mediating role of hedonic value in the relationship between customer experience and behavioral intentions, the current research has found evidence for same.

Overall, this study progresses knowledge and provides practical and empirical insights into a question that has remained fundamentally unaddressed in the current customer experience literature: what mediating role does customers' perceived value play in the relationship between customer experience and behavioral intentions? This study reveals, among other things, that customer's perceived hedonic value is germane in influencing the relationship between customer experience and behavioral intentions. The study also found that though customer's perceived utilitarian value is important, it may not necessarily affect the relationship between customers' experience and their future behavioral dispositions.

\subsection{Theoretical Implications}

The current study progresses theory by extending the expectancy disconfirmation theory on a burgeoning and highly relevant concept-customer experience. Evidence within the current literature about the outcomes of customer experience shows a paucity of research grounded in the expectancy disconfirmation theory. The current study, therefore, modestly contributes to theory by providing empirical support from a customer experience, customer perceived value and behavioral intention perspective for this largely recognized theory (Santos \& Boote, 2003; Diehl \& Poynor, 2010; Patterson et al. 1996; Hsu et al., 2006) with a conceptual framework that depicts good explanatory power. Additionally, the literature on customer experience exhibits less research that integrates and examines the relationships among the constructs adopted in this study, especially the mediating roles of both perceived hedonic and utilitarian value. Prior research either studied the relationship among these constructs in isolation or with different constructs (see for instance Shaw \& 
Ivens, 2005; Ding et al., 2010; Johnston \& Clark, 2008; Meyer, 2007), bringing to bear, the importance for fresher empirical examination, for validation and theory building. Further, the current research contributes to knowledge by presenting outcomes that evaluates multiple interdependencies among the variables used as well as utilizing data from the restaurant setting.

\subsection{Managerial Implications}

Gathering wide-ranging insights relative to customer experience and the role perceived hedonic and utilitarian values play in influencing its effect on customers' behavioral intentions in the restaurant setting offers validity for normative guidelines for handling issues related to customer experience and its allied concepts. Noteworthy findings in the current research could be gleaned from seven main perspectives; that customer experience has a positive and significant effect on behavioral intentions; that customer experience has a positive and significant effect on effect on hedonic value; that customer experience has a positive and significant effect on utilitarian value; that hedonic value has a positive and significant effect on behavioral intention; that utilitarian value has a negative but significant effect on behavioral intention; that hedonic value mediates the relationship between customer experience and behavioral intentions, and finally, that utilitarian value does not mediate the relationship between customer experience and behavioral intentions.

Consequently, to enhance customer's experience in restaurants, managers should enhance their experience through offering a variety of menu items, serving tasty food, present food in a visually appealing manner, offering best possible price plan, using visually appealing interior decorations, providing clean furniture, keeping a very comfortable temperature and ambience, insisting that the staff are friendly and helpful, ensuring that customers are given individual attention and insisting that staff are always available to serve customers at any time. Similarly, to enhance customers' perceived value from patronizing a restaurant and to ensure that they behave positively towards the restaurant, management must ensure that music played in the restaurant entertains customers, the mood in the restaurant makes customers feel exotic, the aesthetics are fun and unique, the cost of the food is reasonable, there are a variety of menu choices as well as provision of food that is healthy as these touch on the hedonic and emotional aspects of the customers' experience.

\subsection{Limitations and Future Research Directions}

The current study comes along with some drawbacks that prompt curious avenues for further research. First, this study is limited to only the restaurant/food industry. Therefore, the findings are only within the ambit of this industry and scholars as well as managers should exercise caution in universally generalizing it with other contexts. Additionally, the hypotheses generated in this study were tested using customers from a single country, is cross-sectional and therefore, may not connote static effects in other contexts. Similarly, because different contexts and industries differ, there are avenues for additional research to validate and substantiate the relationship among the constructs as well as the findings from this study. Also, the effects tested in this study are relationships and not causalities. The concepts examined in this research are relevant across various economic contexts. Hence, these findings open new debates on the phenomenon under study, specifically the possible disparities that may exist between customer experience and both perceived hedonic and utilitarian value and why utilitarian value could not mediate the relationship between customer experience and behavioral intentions. Also further research that adopts different mediating variables or outcomes of customer experience like customer satisfaction or trust will reveal profound insights.

\section{Conclusions}

The current study set out to empirically test the effect of customer experience on customer perceived value and behavioral intentions while assessing the mediating role of customer perceived value in South Korean restaurants. The outcome of the research reveals that customers' experiences in restaurants are germane to 
their behavioral intentions. Additionally, the research reveals that customers' experiences are very critical to both their perceived hedonic and utilitarian values respectively. Similarly, hedonic value positively and significantly predicts behavioral intents while utilitarian value is negative but significantly related to behavioral intentions. The study further finds support for a mediating effect of hedonic value on the relationship between customer experience and behavioral intentions.

\section{References}

[1] Anderson, J. C., \& Gerbing, D. W. (1988). Structural equation modeling in practice: A review and recommended two-step approach. Psychological bulletin, 103(3), 411.

[2] Arnould, E. A. P., \& Cost, L. (1993). River magic: Extraordinary experiences and the extended service encounter. Journal of Consumer Research, 20(1), 24-45.http://dx.doi.org/10.1086/209331

[3] Bagozzi, R. P., \& Yi, Y. (1988). On the evaluation of structural equation models. Journal of the academy of marketing science, 16(1), 74-94.

[4] Bagozzi, R. P., \& Yi, Y. (2012). Specification, evaluation, and interpretation of structural equation models. Journal of the academy of marketing science, 40(1), 8-34.

[5] Barsky, J., \&. Nash, L. (2002). Evoking emotion: affective keys to hotel loyalty. Cornell Hotel and Restaurant Administration Quarterly, 43(1), 39-46.http://dx.doi.org/10.1016/S0010-8804(02)80007-6 (Schmitt, 1999).

[6] Berry, L. L., \& Carbone, L. P. (2007). Build loyalty through experience management. Quality progress, 40(9), 26.

[7] Bhattacherjee, A., \& Premkumar, G. (2004). Understanding changes in belief and attitude toward information technology usage: A theoretical model and longitudinal test. MIS quarterly, 229-254.

[8] Bishnoi, V. K., \& Kumar, A. (2016). Aaker's brand personality scale is not universal-explanation and reasons for bikes in India. Journal of Marketing Analytics, 4(1), 14-27.

[9] Bitner, M. J., \& Hubbert, A. R. (1994). Encounter satisfaction versus overall satisfaction versus quality. Service quality: New directions in theory and practice, 34, 72-94.

[10] Burgess, S. M., \& Steenkamp, J. B. E. (2013). Introduction to the special issue on marketing in emerging markets. International journal of research in marketing, 30(1), 1-3.

[11] Byrne, B. M. (2013). Structural equation modeling with LISREL, PRELIS, and SIMPLIS: Basic concepts, applications, and programming. Psychology Press.

[12] Carbone, L. P., \& Haeckel, S. H. (1994). Engineering customer experiences. Marketing management, 3(3), 8-19.

[13] Carbone, L.P. (2004), Clued In: How to Keep Customers Coming Back Again and Again, PrenticeHall, Upper Saddle River, NJ.

[14] Chen YS (2008). The driver of green innovation and green image - green Core competence. J. Bus. Ethics, 81(3): 531-543. (Patterson et al. 1996;

[15] Dawar, N. D. N., \& Chattopadhyay, A. (2002). Rethinking marketing programs for emerging markets. Long Range Planning, 35(5), 457-474.

[16] DeVellis Robert, F. (2003). Scale development: theory and applications.

[17] Diehl, K., \& Poynor, C. (2010). Great expectations?! Assortment size, expectations, and satisfaction. Journal of Marketing Research, 47(2), 312-322.

[18] Donovan, Robert J. and John R. Rossiter (1982), "Store Atmosphere: An Environmental Psychology Approach," Journal of Retailing, 58 (Spring), 34-57.

[19] Dou, X., Zhu, X., Zhang, J. Q., \& Wang, J. (2019). Outcomes of entrepreneurship education in China: A customer experience management perspective. Journal of Business Research.

[20] Fallon, P., \& Schofield, P. (2003). First-timer versus repeat visitor satisfaction: the case of Orlando, Florida. Tourism Analysis, 8(2), 205-210.

[21] Festinger, L. (1957). A Theory of Cognitive Dissonance, Evanston, ILL, Row, Peterson. Sava, F.(2004). Analiza datelor în cercetarea psihologică. Metode statistice complementare. Cluj-Napoca: Editura ASCR.

[22] Finkelstein, J. (1989). Dining Out. A Sociology of Modern Manners. Polity Press: Cambridge.

[23] Flanagan, P., Johnston, R. and Talbot, D. (2005), "Customer confidence: the development of a "preexperience" concept", International Journal of Service Industry Management, 16 3/4, 373-84. 
[24] Flynn, L. R., \& Pearcy, D. (2001). Four subtle sins in scale development: some suggestions for strengthening the current paradigm. International Journal of Market Research, 43(4), 1-14.

[25] Fornell, C., \& Larcker, D. F. (1981). Structural equation models with unobservable variables and measurement error: Algebra and statistics.

[26] Gentile, C., Spiller, N., \& Noci, G. (2007). How to sustain the customer experience:: An overview of experience components that co-create value with the customer. European management journal, 25(5), 395-410.

[27] Goleman, D., (1996), Emotional Intelligence, Bloomsbury, London

[28] Gotlieb, J., Grewal, D. and Brown, S. (1994), Consumer satisfaction and perceived quality: complementary or divergent constructs?. Journal of applied psychology, 79 (6), 875-85

[29] Grönroos, C. (1997). Value-driven relational marketing: from products to resources and competencies. Journal of marketing management, 13(5), 407-419.

[30] Gummesson, E. (2014). Productivity, quality and relationship marketing in service operations: A revisit in a new service paradigm. International Journal of Contemporary Hospitality Management, 26(5), 656-662.

[31] Ha, J., \& Jang, S. S. (2009). Perceived justice in service recovery and behavioral intentions: The role of relationship quality. International Journal of Hospitality Management, 28(3), 319-327.

[32] Hair, J. F., Anderson, R. E., Babin, B. J., \& Black, W. C. (2010). Multivariate data analysis: A global perspective, 7.

[33] Hsu, S. H., Chen, W. H., \& Hsieh, M. J. (2006). Robustness testing of PLS, LISREL, EQS and ANN-based SEM for measuring customer satisfaction. Total Quality Management \& Business Excellence, 17(3), 355-372.

[34] Hulten, B., Broweus, N., \& Van Dijk, M. (2009). Sensory marketing. Hamsphire, United Kingdom: Palgrave-Macmillan.http://dx.doi.org/10.1057/9780230237049 (Lindsorm, 2005;

[35] Johnston, R., \& Clark, G. (2008). Service operations management: improving service delivery. Pearson Education.

[36] Johnston, R., \& Kong, X. (2011). The customer experience: a road-map for improvement. Managing Service Quality: An International Journal, 21(1), 5-24.

[37] Jones, M.A., Reynolds, K.E., Arnold, M.J., 2006. Hedonic and utilitarian shoppingvalue: investigating differential effects on retail outcomes. Journal of BusinessResearch 59, 974-981

[38] King, R. A., Racherla, P., \& Bush, V. D. (2014). What we know and don't know about online wordof-mouth: A review and synthesis of the literature. Journal of interactive marketing, 28(3), 167-183.

[39] Kranzbühler, A. M., Kleijnen, M. H., Morgan, R. E., \& Teerling, M. (2018). The multilevel nature of customer experience research: an integrative review and research agenda. International Journal of Management Reviews, 20(2), 433-456.

[40] LaSalle, D. and Britton, T.A. (2003) Priceless: Turning ordinary products into extraordinary experiences, Harvard Business School Press, Boston.

[41] LeDoux, J. (1996). Emotional networks and motor control: a fearful view. In Progress in brain research, 107, 437-446. Elsevier.

[42] Macionis, J. J., \& Plummer, K. (1997). Sociology. New York: Prentice Hall. Olsen (1993)

[43] Mascarenhas, O. A., Kesavan, R., \& Bernacchi, M. (2006). Lasting customer loyalty: a total customer experience approach. Journal of consumer marketing, 23(7), 397-405.

[44] Mattila, A. S. (2004). The impact of service failures on customer loyalty: The moderating role of affective commitment. International Journal of Service Industry Management, 15(2),134-149.

[45] Meyer, C., \& Schwager, A. (2007). Understanding customer experience. Harvard business review, 85(2), 116.

[46] Nasermoadeli, A., Ling, K. C., \& Maghnati, F. (2013). Evaluating the impacts of customer experience on purchase intention. International Journal of Business and Management, 8(6), 128.

[47] Oliver, C. (1997). Sustainable competitive advantage: combining institutional and resource-based views. Strategic management journal, 18(9), 697-713.

[48] Oliver, R. L. (1980). A cognitive model of the antecedents and consequences of satisfaction decisions. Journal of marketing research, 17(4), 460-469.

[49] Overby, J. W., \& Lee, E. J. (2006). The effects of utilitarian and hedonic online shopping value on consumer preference and intentions. Journal of Business research, 59(10-11), 1160-1166. 
[50] Park, C. (2004). Efficient or Enjoyable? Consumer values of eating-out and fast food restaurant consumption in Korea,

[51] Patterson, P. G., Johnson, L. W., \& Spreng, R. A. (1996). Modeling the determinants of customer satisfaction for business-to-business professional services. Journal of the academy of marketing science, 25(1), 4-17.

[52] Pine, B. J., \& Gilmore, J. H. (1998). Welcome to the experience economy. Harvard business review, 76, 97-105.

[53] Prahalad, C. K., \& Ramaswamy, V. (2004). Co-creating unique value with customers. Strategy \& leadership, 32(3), 4-9.

[54] Pullman, M. E., \& Gross, M. A. (2004). Ability of experience design elements to elicit emotions and loyalty behaviors. Decision sciences, 35(3), 551-578.

[55] Purves, D., Augustine, G.J., Fitzpatrick, D., Katz, L.C., LaMantia, A. S., and Williams, S.M., (2001), Neuroscience,2nded, Sinauer Associates, Sunderland, Massachusetts

[56] Rajaobelina, L. (2018). The impact of customer experience on relationship quality with travel agencies in a multichannel environment. Journal of Travel Research, 57(2), 206-217.

[57] Roos, I. (1999). Switching processes in customer relationships. Journal of Service Research, 2(1), 68-85.

[58] Santos, J., \& Boote, J. (2003). A theoretical exploration and model of consumer expectations, postpurchase affective states and affective behaviour. Journal of Consumer Behaviour: An International Research Review, 3(2), 142-156.

[59] Schmitt, B. (1999). Experiential marketing. Journal of marketing management, 15(1-3), 53-67.

[60] Shaw, C. and Ivens, J. (2005), Building Great Customer Experiences, Prentice-Hall, London.

[61] Shaw, C., \& Ivens, J. (2002). Building great customer experiences (241). London: Palgrave.

[62] Sheth, J. N. (2011). Impact of emerging markets on marketing: Rethinking existing perspectives and practices. Journal of marketing, 75(4), 166-182.

[63] Sheth, J. N., Newman, B. I., \& Gross, B. L. (1991). Consumption values and market choices: Theory and applications.

[64] Spangenberg, E. R., Voss, K. E., \& Crowley, A. E. (1997). Measuring the hedonic and utilitarian dimensions of attitude: a generally applicable scale. ACR North American Advances.

[65] Swan, J. E., \& Oliver, R. L. (1989). Post purchase communications by consumers. Journal of retailing, 65(4), 516.

[66] Sweeney, J. C., \& Soutar, G. N. (2001). Consumer perceived value: The development of a multiple item scale. Journal of retailing, 77(2), 203-220.

[67] Swinyard, W. R. (1993). The effects of mood, involvement, and quality of store experience on shopping intentions. Journal of consumer research, 20(2), 271-280.

[68] Teo, T.S.H. (2001), Demographic and motivation variables associated with Internet usage activities, Internet Research, 11 (2), 125-137.

[69] Verhoef, P. C., Lemon, K. N., Parasuraman, A., Roggeveen, A., Tsiros, M., \& Schlesinger, L. A. (2009). Customer experience creation: Determinants, dynamics and management strategies. Journal of retailing, 85(1), 31-41.

[70] Voss, K. E., Spangenberg, E. R., \& Grohmann, B. (2003). Measuring the hedonic and utilitarian dimensions of consumer attitude. Journal of marketing research, 40(3), 310-320.

[71] Xin Ding, D., Hu, P. J. H., Verma, R., \& Wardell, D. G. (2010). The impact of service system design and flow experience on customer satisfaction in online financial services. Journal of Service Research, 13(1), 96-110.

[72] Yang, Z. Y., \& He, L. Y. (2011). Goal, customer experience and purchase intention in a retail context in China: An empirical study. African Journal of Business Management, 5(16), 6738-6746.

[73] Zeithaml, V. A. (1988). Consumer perceptions of price, quality, and value: a means-end model and synthesis of evidence. Journal of marketing, 52(3), 2-22.

[74] Zomerdijk, L. G., \& Voss, C. A. (2010). Service design for experience-centric services. Journal of Service Research, 13(1), 67-82. 